\title{
The Relationship of Attitudes towards Profession, Work Motivation and Work Dis- cipline on Teacher Performance at State Junior High Schools in Hulu Sungai Ten- gah Regency
}

\author{
Zulkipli *, Mahrita, Ahmad Suriansyah \\ Master Program of Education Management, Universitas Lambung Mangkurat, Banjarmasin 70123, Indonesia
}

Article history:

Submission September 2020

Revised December 2020

Accepted December 2020

*Corresponding author:

E-mail: zulkiplid60@gmail.com

\begin{abstract}
The objectives to be achieved in this research are (1) Describing attitudes towards the profession, work motivation, work discipline, and teacher performance at State Junior High Schools in Hulu Sungai Tengah Regency, and (2) Analyzing the direct relationship between attitudes towards the profession, work motivation and work discipline with teacher performance. It is quantitative research with a causal relationship design. The population was 348 teachers of State Junior High Schools in the Hulu Sungai Tengah Regency. Sampling was carried out using the Proportionate Random Sampling technique to obtain a sample of 186 teachers. A questionnaire was used as the only means of collecting data. Data analysis to test hypotheses using Path analysis techniques. The results of this study are: (1) there is a direct relationship: (a) between attitudes towards the profession and the discipline of work of teachers; (b) between work motivation and work discipline of teachers; (c) between attitudes towards the profession and teacher performance; (d) between work motivation and teacher performance; (e) between work discipline and teacher performance; and (2) there is no indirect relationship: (a) between attitudes towards the profession and teacher performance through work discipline; (b) between work motivation and teacher performance through work discipline at State Junior High Schools in Hulu Sungai Tengah Regency. Based on the results of this study it is suggested that the school should conduct activities that can maintain and improve teachers' attitude towards the professions, motivation, and discipline.
\end{abstract}

Keywords: Attitudes towards the profession, work motivation, work discipline, performance

\section{Introduction}

Getting an education is a human right, and education has an essential task in preparing young people to participate in society (Veugelers \& Groot, 2019). In general, education is an effort to transfer or share knowledge and values (life) from one generation to another (Baharuddin \& Dalle, 2019). Education is also often open, which is open to all learning, anywhere, anytime. There is a formal primary education system.

According to Crane et al. (2010) which in Indonesia enforces nine years of compulsory education. An education that is open to all is the main thing that needs to be done to optimize the benefits of education for people's lives is to create quality and sustainable education. Besides, educational institutions are also important in the placement of resources such as school principals, teachers, and those who take care of administration. This is important to note because education's success is related to opportunities in the education system and has a relationship with the individual characteristics of students and possibly parents. Learning is an essential key in this regard (Udas et al., 2016), including the teacher's role. Teachers have a crucial role in creating the quality of education in schools. The teacher is a 'professional identity,' which is attached as a complex state related to 
knowledge, justification, and appearance. Teachers' professional identity is also embedded as a carrier of hope for the future because, in schools (educational institutions), the future is built (Lauwers, 2019). The teacher then functions as an agent of change, both at the classroom and school level (van der Heijden et al., 2015).

Based on this concept, it is not surprising that teachers must be professional and competent in their field. Therefore, teacher training is often held for every level of education. This is done so that teachers, as agents of knowledge and change, have a commitment, responsibility, robust assessment, self-evaluation abilities, and concern for what other people do (Edwards, 2015). In this case, the teacher may change in the dimensions of curriculum, teaching, learning, and patterns, such as changes in their practice and values (Tam, 2015). Personal and professional experience has become a significant influence in the development of teacher identity, which is also formed from specific contexts and discourses that can differ with changing times (Sachs, 2016), and how they can survive and adapt to create their place, which unconsciously shows the quality of their profession.

The attitude of teachers who show high professions has the quality to provide more energy and responsibility in supporting teaching and learning process activities and school success (Suhaimi \& Efendi, 2018). It can be seen that teacher performance affects the growth and development of education. A teacher's performance can be seen according to the duties and responsibilities that must be done every day (Kuncoro \& Dardiri, 2017). Experience shows that implementing a performance-based management system requires a clear goal for example, in natural sciences, it is for the growth of scientific literacy (Ramseger et al., 2018), and maximizing learning even from kindergarten to grade 12 students. Although ideal performance management is very different from actual problematic practices (Blackman et al., 2015). It cannot be denied that the teacher's efforts to provide instruction and learning will influence students informing goals and their educational orientation (Throndsen \& Turmo, 2013; Poernamawijaya et al., 2018). For example, developing a directly related curriculum to student goals will improve their academic abilities (Myers, 2008).

So, it is not surprising that another factor that is thought to be related to teacher performance is their work motivation (Hakanen et al., 2006). This is because teachers have different perceptions of themselves as professionals and task responsibilities that they consider essential (McKenney \& Visscher, 2019) even though their main task remains the same: designing, learning, enforcing rules reflecting from many directions. These different things can be seen as motivations in a teacher's professional self. This motivation itself is understood as a relevant part of the instructional design process. Motivation is an ongoing process (Goudas et al., 2011), which is very different, associated with the individual as a whole. It can be seen that motivation depends on specific individuals and situations (Thijs, 2011), which shape the desire to achieve a goal (Hays \& Hill, 2001). So, it can be seen that there is motivation, which, although it varies from one teacher to another, is related to teacher performance. The research results conducted by Normianti (2019) also show a direct relationship between work motivation and teacher performance. Motivation is also defined as the performance of an activity that is used as a tool in obtaining the desired result (Teo et al., 1999). Therefore, concerning motivation, teachers must always instill a positive attitude. The positive attitude of teachers towards their profession is critical in improving the quality of education. The quality of education can be seen from a productive education system in which inputs are transferred into outcomes (Scheerens, 2004) from learning between teachers and students.

Apart from the two variables above, the teacher must also have a high discipline attitude to carry out the tasks that are their responsibility. The teaching and learning process can go according to plan, not just stop. Discipline is to achieve compliance (Turner, 2006), which can be seen as an effort to carry out many things or tasks following rules and deadlines, and so on. According to Aritonang, work discipline is the teacher's perception of the teacher's attitude in terms of self-order and selforder conducted by the teacher without causing an offense that is detrimental to him, others, or the environment (Barnawi \& Arifin, 2012). Furthermore, Sagala (2013) states that the success of applying discipline lies in the personal discipline of the organization's members. Self-discipline in everyday life is a crucial parameter for improving learning outcomes (Gorbunovs et al., 2016). The above conditions require an evaluation of policies 
in the education sector. Undisciplined teacher work will generally reduce the level of productivity, quality, and image of the school, which is even worse than the decline in student achievement, which in general will result in lower quality teacher performance.

According to Romli (2011), motivation to work is very important for an organization's high and low productivity or institution. This is because motivation is an action (Potter \& Ware, 1987) that moves from within (Locke \& Baum, 2006) as a force that causes and triggers subsequent actions, including the level of productivity. Meanwhile, Kanfer (2012) defines work as a psychological process that determines (or encourages) the direction, intensity, and persistence in carrying out actions in a sustainable manner based on their characteristics and experiences with their work. Performance appraisal is an activity that is very important because it can be used to measure the success of an organization.

According to Mejia (2013) defines performance appraisal as the identification, measurement, and management of a person's performance in the organization. According to performance, evaluating a person's behavior determines how well or poorly someone has done and completed a task or job.

Based on the description above, the focus of this research is the relationship between attitudes towards the profession and work discipline, the relationship between work motivation and work discipline, the relationship between attitudes towards the profession and teacher performance, the relationship between work motivation and teacher performance, the relationship between work discipline and teacher performance, the relationship between attitudes towards the profession and teacher performance, profession and teacher performance through work discipline and the relationship between work motivation and teacher performance through work discipline.

\section{Material and Methods}

The research method used is quantitative research methods. Quantitative research analyzes data in numerical form to determine conclusions (Albers, 2017). The main objective of quantitative research is to construct accurate and reliable calculations that allow for statistical analysis. Following the opinion (Beins, 2016) that the purpose of path analysis is to provide a quantitative estimate of the causal relationship between variables. Relationships that take place in one direction and are viewed through different paths. Thus, the research design used in this study is a causal relationship between variables. The pattern of the relationship between the variables studied, namely the independent variable (free), are attitudes towards the profession (X1) and work motivation $(\mathrm{X} 2)$, and the intervening variable is work discipline (Z). Meanwhile, the dependent variable (bound) (Y) is teacher performance.

\section{Population}

According to Sugiyono (2014), a population is an area of generalization with objects or subjects with specific qualities and characteristics following the research objectives. In this study, the population is all teachers with the status of State Junior High School Civil Servants in Hulu Sungai Tengah Regency, which consisted of 35 State Junior High Schools with a total population of 348 teachers.

\section{Samples}

The sample is part of the population's number and characteristics (Sugiyono, 2014). The sample is a sampling technique used by some members of the population who are drawn using specific techniques. Sampling in this study using Proportionate Random Sampling. Sampling was carried out using the Slovin formula (Arikunto, 2016) as follows.

$$
\begin{aligned}
& \mathrm{n}=\mathrm{N} /\left(1+\left(\mathrm{N}_{\mathrm{x} \mathrm{e}} \mathrm{e}^{2}\right)\right) \\
& \text { Information: } \\
& \mathrm{n}=\text { amount of sample } \\
& \mathrm{N}=\text { amount of population } \\
& \mathrm{e} \quad=\text { fault tolerance limit }
\end{aligned}
$$

From the calculation with an error rate of $5 \%$, the number of samples in the study was 186 teachers.

\section{Results and Discussion \\ Characteristics of respondents}

Characteristics of respondents from a total of 186 as much as $27.42 \%$ consisting of men and $72.58 \%$ women. So it shows more female respondents. Most of the respondents in this study were dominated by teachers aged 40-49 years. Most of 
the respondents in this study were dominated by teachers who had a service period of 16-20 years.

\section{Testing requirements analysis}

Characteristics of respondents from a total of 186 as much as $27.42 \%$ consisting of men and $72.58 \%$ women. So, it shows more female respondents.

\section{Normality test}

From the test results, it can be seen that Asymp. Sig (2-tailed) for the attitude variable towards the profession is 0.300 , work motivation is 0.140 , work discipline is 0.290 , and teacher performance is 0.078 . This is because the Sig value is greater than 0.05 (significance level). Therefore, the data for the variables of attitudes towards the profession, work motivation, work discipline, and teacher performance are normally distributed.

\section{Multicolonierity test}

Multicollinearity or correlation between independent variables can be known by paying attention to the regression estimation output in the Coefficients table, especially in Collinearity Statistics, namely the VIF number and tolerance number from data processing through the SPSS Version 22 Application program. The VIF value for the attitude variable towards profession (X1) is 1.179 , the work motivation variable (X2) is 1.068 , and the work discipline variable $(\mathrm{Y})$ is 1.252 , none of which is more than 10. Meanwhile, the tolerance value for the attitude variable towards profession (X1) of 0.848 , work motivation variable (X2) of 0.936 , and work discipline variable $(\mathrm{Y})$ of 0.798 , which is less than 0.10 . Thus, it can be concluded that there is no multicollinearity between the independent variables in the regression model.

\section{Autocorrelation test}

The regression estimation output results in the summary model table above, the DW (DurbinWatson) value is 2.164. If this value is compared with the table value with the number of independent variables $3(\mathrm{k}=3)$ and a sample size of 168 , the value $(\mathrm{du})=1.7929$ is obtained. Because the DW value of 2.164 is greater than the upper limit value $(\mathrm{du})=1.7929$ and less than $(4-\mathrm{du})=2.2701$, it is stated that there is no autocorrelation in the regression model.

\section{Heteroscedasticity test}

Heteroscedasticity is the inequality of residual variants from one observation to another. Based on the regression estimation output as the Glejser test, it is stated that the significance probability of the attitude towards profession variable is 0.649 , the significance probability of the work motivation variable is 0.689 , and the significance probability of the work discipline variable is 0.169 , which are far above the $5 \%$ or 0.050 significance level. Based on the results of the regression model testing above, it can be concluded that the resulting regression model has met the requirements of the classical assumptions. Thus, the regression model produced in this study is a predictive model that meets the classical assumption test.

\section{Hypothesis testing}

Hypothesis testing uses the SPSS version 22 application program with the following results.

\section{The direct relationship between attitudes towards} the profession and the work discipline of teachers

The results of hypothesis testing with Path Analysis as a continuation of multiple linear regression analysis obtained the attitude variable's output toward the profession with a sig value of 0,000 . This sig value is smaller than the significance level of 0.05 , or the value of $0.000<0.05$. The attitude variable towards the profession obtained a t-value of 5.709, which is greater than the $\mathrm{t}$ table at the 0.05 significance level with df (1861) of 1.972. Ho is rejected and $\mathrm{Ha}$ is accepted. This means that there is a direct relationship between attitudes towards the profession and teacher work discipline. A positive $t$ value indicates that the profession's attitude variable has a direct relationship with teacher work discipline. The findings in this study are in line with research conducted by (Syarwani, 2018), which found a significant contribution to the teaching profession's attitude towards teacher work discipline. Attitude activities towards the teaching profession can provide an increase in teacher work performance. Following these two opinions implies that if the teacher has a high professional attitude, the teacher will also have a good work discipline. 
The direct relationship between work motivation and teacher work discipline

The results of hypothesis testing with Path Analysis obtained the work motivation variable's output with a sig value of 0.001 . This sig value is smaller than the significance level of 0.05 , or the value of $0.001<0.05$. The work motivation variable obtains a $t$-value of 3.506 , greater than the $t$ table at a significance level of 0.05 with df (186 1) of 1.972 so that Ho is rejected and $\mathrm{Ha}$ is accepted. This means that there is a direct relationship between work motivation and teacher work discipline.

Furthermore, the structural equation of the first sub-structure path for the two variables of attitudes towards the profession and work motivation towards R Square's teacher work discipline value is 0.202 . This shows that variations in the variable attitudes towards the profession and work motivation can explain $20.2 \%(0.202 \times 100 \%)$ variations in teacher work discipline variables. In comparison, the remaining $79.8 \%(100 \%-20.6 \%)$ is explained by factors - other factors not discussed in this study. Furthermore, the path coefficient value of attitude towards profession with work discipline ( $\rho$ YX1) is 0.377 , the value of the path coefficient of motivation with work discipline ( $\rho$ YX2) is 0.232 , and the factor coefficient value $\varepsilon 1$ is $\varepsilon 1=\sqrt{ }(1-0.202)=0.893$.

The direct relationship between attitudes towards the profession and teacher performance

The hypothesis testing results with Path Analysis obtained the sig output for the attitude variable towards the profession, and the sig value was 0.044 . This sig value is smaller than the significance level of 0.05 , or the value of 0.044 $<0.05$. The attitude variable towards profession obtained a t-value of 2.029, greater than the t-table at the significance level of 0.05 with df (186 - 1) of 1.972. Ho was rejected, and Ha was accepted. This means that there is a direct relationship between attitudes towards the profession and teacher performance.

\section{The direct relationship between work motivation and teacher performance}

The hypothesis testing results with Path Analysis obtained the output of the work motivation variable obtained a sig value of 0.030 . This sig value is smaller than the significance level of
0.05 , or the value of $0.030<0.05$. The work motivation variable obtains a t-value of 2.191 , which is greater than the t-table at a significance level of 0.05 with df $(186-1)$ of 1.972 so that Ho is rejected and Ha is accepted. This means that there is a direct relationship between work motivation and teacher performance. This study's results are in line with research conducted by (Noor, 2019) that there is a direct relationship between work motivation and the performance of high school teachers in East Banjarmasin District. Therefore, teacher performance awards are demanded, which must be based on the distribution of workloads.

\section{The direct relationship between work discipline and teacher performance}

The results of hypothesis testing with Path Analysis obtained the work discipline variable's output with a sig value of 0,000 . This sig value is smaller than the significance level of 0.05 or the value of $0.000<0.05$. The work discipline variable obtained a $t$-value of 3.630, greater than the t table at a significance level of 0.05 with df (186 - 1) of 1.972 so that Ho was rejected, and Ha was accepted. This means that there is a direct relationship between work discipline and teacher performance.

The indirect relationship between attitudes towards the profession and teacher performance is through work discipline

Based on data on the R Square value of 0.173 . This shows that $17.3 \%(0.173 \times 100 \%)$ of variations in teacher performance variables can be explained by variations in the variables of attitudes towards the profession, work motivation, and work discipline. Meanwhile, the remaining $82.7 \%$ $(100 \%-17.3 \%)$ was explained by other factors not discussed in this study. Furthermore, the path coefficient value of attitudes towards the profession and teacher performance ( $\rho Z X 1)$ is 0.149 . The value of the path coefficient of motivation in the direct relationship between the attitude variable towards the profession and teacher performance is 0.149 . Meanwhile, the indirect relationship between attitudes towards the profession and teacher performance through work discipline is the beta value of the relationship between the attitude variable towards the profession and the work discipline of teachers multiplied by the beta value of the relationship between work discipline variables 
and teacher performance, namely: $0.377 \times 0.274=$ 0.103 . The results of this calculation indicate that the value of the direct relationship between attitudes towards the profession and teacher performance is greater than the indirect relationship (0.149>0.103), so that Ho is accepted and $\mathrm{Ha}$ is rejected, which means that there is a direct relationship between attitudes towards the profession and teacher performance without going through work discipline in SMP. The country in Hulu Sungai Tengah Regency. This study is in line with research conducted by Syarwani et al. (2018) that there is a significant influence on work motivation on teacher performance in public vocational high schools in Banjarmasin. Teacher performance is the teacher's workability as seen from the level of achievement and completion of tasks that are their responsibility following predetermined conditions.

The indirect relationship between attitudes towards the profession and teacher performance is through work discipline

The beta value of the direct relationship between work motivation and teacher performance is 0.153. Meanwhile, the indirect relationship between work motivation and teacher performance through work discipline is the beta value of the relationship between work motivation and teacher work discipline multiplied by the beta value of the relationship between work discipline and teacher performance, namely: $0.232 \times 0.274=0.063$. The results of this calculation indicate that the value of the direct relationship between work motivation and teacher performance is greater than the indirect relationship $(0.153>0.063)$, so that $\mathrm{Ho}$ is accepted and $\mathrm{Ha}$ is rejected, which means that there is a direct relationship between work motivation and teacher performance without going through work discipline at State Junior High School in Hulu Sungai Tengah District. This study's findings are also in line with research conducted by (Suhailuddin, 2013) that there is a significant relationship between attitudes towards the teaching profession and teacher work performance. The existence of a direct relationship between attitudes towards the profession and teacher performance indicates that attitudes towards teachers' profession tend to directly determine teacher performance compared to teacher work discipline.

\section{Conclusion}

Based on the results of research that have been carried out, analysis, and hypothesis testing, the conclusions of this study are obtained:

1. There is a direct relationship between attitudes towards the profession and teachers' work discipline. The prediction model for the direct relationship between attitudes towards the profession and teacher work discipline, namely: $\hat{\mathrm{Y}}=47.925+0.492 \mathrm{X} 1$. This means that attitudes towards the profession have a positive relationship with teacher work discipline. The higher the attitude towards the profession, the higher the work discipline of the teacher.

2. There is a direct relationship between work motivation and teacher work discipline in the predictive model of a direct relationship between work motivation and teacher work discipline, namely: $\hat{Y}=47.925+0.240 \mathrm{X} 2$. This means that work motivation has a positive relationship with teacher work discipline. The higher the work motivation, the higher the work discipline of the teacher.

3. There is a direct relationship between attitudes towards the profession and teacher performance. The prediction model has a direct relationship between attitudes towards the profession and teacher performance: $\dot{Z}=55.743+0.185 X 1$. This means that attitudes towards the profession have a positive relationship with teacher performance. The higher the attitude towards the profession, the higher the teacher's performance.

4. There is a direct relationship between work motivation and teacher performance. The prediction model for the direct relationship between work motivation and teacher performance is $\dot{Z}=55.743+0.151 \mathrm{X} 2$. This means that work motivation has a positive relationship with teacher performance. The higher the work motivation, the higher the teacher's performance.

5. There is a direct relationship between work discipline and teacher performance at State Junior High Schools in Hulu Sungai Tengah Regency. The prediction model for the direct relationship between work discipline and teacher performance is $Z=55.743+0$, 
$0.262 \hat{Y}$. This means that work discipline has a positive relationship with teacher performance. The higher the work discipline, the higher the teacher's performance.

6. There is a direct relationship between attitudes towards the profession and teacher performance without going through work discipline at State Junior High Schools in Hulu Sungai Tengah Regency.

7. The value of the direct relationship between attitudes towards the profession and teacher performance is greater than the indirect relationship (0.149>0.103). This means that attitudes towards the profession and teacher performance have a direct relationship without going through work discipline.

8. There is a direct relationship between work motivation and teacher performance without going through work discipline at State Junior High Schools in Hulu Sungai Tengah Regency.

9. The value of the direct relationship between work motivation and teacher performance is greater than the indirect relationship $(0.153>0.063)$. This means that work motivation and teacher performance have a direct relationship without going through work discipline.

\section{Acknowledgment}

The author thanks to Master Program of Education, Universitas Lambung Mangkurat, Banjarmasin for supporting this research.

\section{References}

Albers, M. J. (2017). Quantitative data analysis - in the graduate curriculum. Journal of Technical Writing and Communication, 47(2), 215-233. https://doi.org/10.1177/0047281617692067

Arikunto, S. (2016). Prosedur penelitian suatu pendekatan praktik,(edisi revisi). Jakarta: Rineka Cipta.

Baharuddin, B., \& Dalle, J. (2019). Transforming learning spaces for elementary school children with special needs. Journal of Social Studies Education Research, 10(2), 344-365.

Barnawi \& Arifin, M. (2012). Kinerja guru profesional: instrumen pembinaan, peningkatan \& penilaian. Yogyakarta: Ar-Ruzz Media.

Beins, B. \&. (2016). Research methods and statistics. New Jersey: Pearson Education Inc.

Blackman, D., West, D., O’Flynn, J., Buick, F., \& O’Donnell, M. (2015). Performance management: creating high performance, not high anxiety. In L. H. Wanna J., Managing Under
Austerity, Delivering Under Pressure: Performance and Productivity in Public Service (pp. 79-102). ANU Press.

Crane, K., Dobbins, J., Miller, L., Ries, C., Chivvis, C., Haims, M., \& . . . Wilke, E. (2010). Education. In Building a More Resilient Haitian State. Santa Monica, CA; Arlington, VA; Pittsburgh, PA: RAND Corporation.

Edwards, A. (2015). Recognising and realising teachers' professional agency. Teachers and Teaching, 21(6), 779-784.

Gorbunovs, A., Kapenieks, A., \& Cakula, S. (2016). Self-discipline as a key indicator to improve learning outcomes in e-learning environment. Procedia - Social and Behavioral Sciences, 231(5), 256-262.

Goudas, M., Biddle, S., \& Fox, K. (2011). Perceived locus of causality, goal orientations, and perceived competence in school physical education classes. British Journal of Educational Psychology, 64(3), 453-463.

Hakanen, J. J., Bakker, A. B., \& Schaufeli, W. B. (2006). Burnout and work engagement among teachers. Journal of School Psychology,43(6), 495-513.

Hays, J. M., \& Hill, A. V. (2001). A preliminary investigation of the relationships between employee motivation/vision, service learning, and perceived service quality. Journal of Operations Management, 19(3), 335-349.

Kanfer, R. e. (2012). Work Motivation: Past, Present, and Future. New York: Routledge Taylor \& Francis Group.

Kuncoro, T., \& Dardiri, A. (2017). Teacher performance and work environment in the instructional process in vocational school. AIP Conference Proceedings, 1887 (1). AIP Publishing.

Lauwers, G. (2019). Reshaping Teacher Training to Get the Right Education System for a Knowledge Society. In K.-W. M.-B. Lauwers G., Rethinking Teacher Education for the 21st Century: Trends, Challenges and New Directions (pp. 43-53). Opladen; Berlin; Toronto: Verlag Barbara Budrich.

Locke, E. A., \& Baum, J. R. (2006). Entrepreneurial motivation. The Psychology of Entrepreneurship, 93-112. Lawrence Erlbaum Associates Publishers

McKenney, S., \& Visscher, A. J. (2019). Technology for teacher learning and performance. Technology, Pedagogy and Education, 28 (2) , 129-132.

Mejia, L. e. (2013). Managing human resources (seventh edition). New Jersey: Pearson Education Inc.

Myers, C. (2008). Divergence in learning goal priorities between college students and their faculty: implications for teaching and learning. College Teaching, 56(1), 53-58.

Noor, S. d. (2019). Relationship Principal Leadership to Work Motivation,Morale teacher and teacher performance of State Junior High Schools. Journal of K6, Education, and Management, 2(1), 15-22.

Normianti, H. (2019). Relationship of transformational leanders of principal,teacher motivation, teacher organization commitments with perfonance of primary school teachers in 
Labuan Amas Selatan, Indonesia . European Journal of Education Studies, 5(11), 3-4.

Poernamawijaya, L. W., Sulaiman, S., Suriansyah, A., \& Dalle, J. (2018). Contribution on supervision of supervisor, principals motivation, kindergarten teacher performance to improving the kindergarten quality in West Banjarmasin, Indonesia. European Journal of Alternative Education Studies, 3(2), 129146. doi:10.5281/zenodo.2261031

Potter, W. J., \& Ware, W. (1987). An analysis of the contexts of antisocial acts on prime-time television. Communication Research, 14(6), 664-686.

Ramseger, J., Anders, Y., Hardy, I., Pauen, S., Sodian, B., Steffensky, M., \& Tytler, R. (2018). The Goal of Science Teaching. In H. d. (Ed.), Early Science Education - Goals and ProcessRelated Quality Criteria for Science Teaching (pp. 175-179). Opladen; Berlin; Toronto: Verlag Barbara Budrich.

Romli, K. (2011). Komunikasi organisasi lengkap. Jakarta: PT Grasindo, Anggota.

Sachs, J. (2016). Teacher professionalism: why are we still talking about it? Teachers and Teaching, 22(4), 413-425.

Sagala, S. (2013). Kemampuan profesional guru dan tenaga kependidikan. Bandung: Alfabeta.

Scheerens, J. (2004). Perspectives on education quality, education indicators and benchmarking. European Educational Research Journal, 3(1), 115-138. https://doi.org/10.2304/eerj.2004.3.1.3

Sugiyono. (2014). Statistik untuk penelitian. Bandung: Alfabeta.

Suhailuddin. (2013). Kontribusi sikap terhadap profesi guru dan kompetens ipedagogik guru terhadap kinerja guru smk negeri kabupaten kapuas. Tesis Program Pascasarjana Magister Manajemen Pendidikan Universitas.
Suhaimi \& Efendi, N. (2018). Hubungan peran kepala sekolah dan sikap terhadap profesi guru dengan prestasi kerja guru SMA Negeri di Kabupaten Hulu Sungai Tengah. Jurnal Ilmiah Kependidikan, 13(1),1-10.

Syarwani, A. d. (2018). The influence of principal leadership style. IJSDR, 3(1), 114-119.

Tam, A. C. (2015). The role of a professional learning community in teacher change: a perspective from beliefs and practices. Teachers and Teaching, 21(1), 22-43.

Teo, T. S., Lim, V. K., \& Lai, R. Y. (1999). Intrinsic and extrinsic motivation in Internet usage. Omega, Elsevier, vol. 27(1), 2537.

Thijs, J. (2011). Ethnic differences in teacher-oriented achievement motivation: A study among early adolescent students in the Netherlands. The Journal of genetic psychology, 172(2), 121140 .

Throndsen, I., \& Turmo, A. (2013). Primary mathematics teachers' goal orientations and student achievement. Instructional Science, 41(2), 307-322.

Turner, B. S. (2006). Discipline . Theory, Culture, \& Society.

Udas, K., Partridge, H., \& Stagg, A. (2016). Open education practice at the University of Southern Queensland. In B. P. (Eds.), Open education: international perspectives in higher education (pp. 321-342). Cambridge, UK: Open Book.

Van der Heijden, H., Geldens, J., Beijaard, D., \& Popeijus, H. (2015). Characteristics of teachers as change agents. Teachers and Teaching: theory and practice, 21(6), 681-699.

Veugelers, W., \& Groot, I. (2019). Theory and Practice of Citizenship Education. In V. W. (Ed.), Education for democratic intercultural citizenship (pp. 14-41). Leiden; Boston: Brill. 